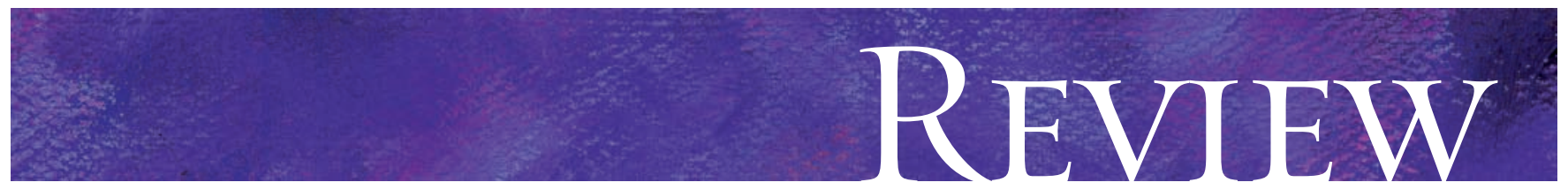

\title{
Type 1 diabetes: pathogenesis and prevention
}

\author{
Kathleen M. Gillespie
}

\section{ABSTRACT}

Type 1 diabetes results from the autoimmune destruction of insulin-producing $\beta$ cells in the pancreas. Genetic and, as yet undefined, environmental factors act together to precipitate the disease. The excess mortality associated with the complications of type 1 diabetes and the increasing incidence of childhood type 1 diabetes emphasize the importance of therapeutic strategies to prevent this chronic disorder. Why is it considered that type 1 diabetes might be preventable? Different strands of diabetes research are coming together to suggest therapeutic targets. Islet cell autoantibody assays make it possible to accurately identify people at risk of future disease. In most cases, a long prodrome provides a window of opportunity to reverse the autoimmune process. Although no current "cure" exists, recent genetic data and preliminary trial results suggest $T$ cells as a target for preventive strategies. Another potentially attainable target is induction of tolerance to the $\beta$-cell proteins such as insulin that are inappropriately recognized. Other strategies involve $\beta$-cell replacement, but currently there are insufficient donor cells available. This may be overcome as the processes controlling the differentiation of pancreatic and nonpancreatic progenitors as well as replication of existing islet $\beta$ cells are unravelled.

CMAJ 2006;175(2):165-70

$\mathrm{T}$ ype I diabetes is characterized by autoimmune destruction of insulin-producing $\beta$ cells in the pancreas by $\mathrm{CD}_{4}+$ and $\mathrm{CD} 8+\mathrm{T}$ cells and macrophages infiltrating the islets. ${ }^{1}$ The disease accounts for about ro\% of all cases of diabetes, occurs most commonly in people of European descent and affects 2 million people in Europe and North America. There is a marked geographic variation in incidence, with a child in Finland being about 400 times more likely than a child in Venezuela to acquire the disease (Fig. I). The current global increase in incidence of $3 \%$ per year is well reported, ${ }^{2}$ and it is predicted that the incidence F of type I diabetes will be $40 \%$ higher in 2010 than in $1998 .{ }^{3}$ This rapid rise strongly suggests that the action of the environment on susceptibility genes contributes to the evolving epidemiology of type I diabetes.

Before safe and rational therapies can be offered in a clinical setting, a detailed understanding of the immune-mediated process that results in type I diabetes is required, as is the ac- curate identification of those at risk of the disease. The immunogenetics of type I diabetes has become the model upon which other complex disorders are studied, and in this article we review the importance of recent insights into the pathogenesis and natural history of type I diabetes and consider current therapeutic strategies.

\section{Genes: How important are they?}

Like other organ-specific autoimmune diseases, type I diabetes has human leukocyte antigen (HLA) associations, but how well are they understood? The HLA on chromosome 6 was the first locus shown to be associated with the disease by candidate gene studies ${ }^{4,5}$ and is considered to contribute about half of the familial basis of type I diabetes. ${ }^{6,7}$ Two combinations of HLA genes (or haplotypes) are of particular importance: $\mathrm{DR}_{4}-\mathrm{DQ}_{8}$ and $\mathrm{DR}_{3}-\mathrm{DQ}_{2}$ are present in $90 \%$ of children with type I diabetes. ${ }^{8} \mathrm{~A}$ third haplotype, DRI5-DQ6, is found in less than $\mathrm{I} \%$ of children with type I diabetes, compared with more than $20 \%$ of the general population, and is considered to be protective. ${ }^{9}$ The genotype combining the 2 susceptibility haplotypes (DR4-DQ8/DR3-DQ2) contributes the greatest risk of the disease and is most common in children in whom the disease develops very early in life. ${ }^{10}$ First-degree relatives of these children are themselves at greater risk of type I diabetes than are the relatives of children in whom the disease develops later. ${ }^{11}$

Candidate gene studies also identified the insulin gene on chromosome II as the second most important genetic susceptibility factor, contributing 10\% of genetic susceptibility to type I diabetes. ${ }^{12}$ Shorter forms of a variable number tandem repeat in the insulin promoter are associated with susceptibility to the disease, whereas longer forms are associated with protection. ${ }^{13}$ Demonstration of increased expression of insulin (mRNA) in the thymus of people with "long" or protective repeats - which suggests more efficient deletion of insulin-specific $T$ cells during induction of central tolerance provides an attractive potential mechanism for the role of the insulin gene in type I diabetes..$^{14,15}$

Over the last decade, whole genome screens have indicated that there are at least 15 other loci associated with type I diabetes, ${ }^{16-18}$ and of those, another 2 genes intimately associated with T-cell activation have been identified recently. An allele of the gene for a negative regulator of T-cell activation, cytotoxic T lymphocyte antigen 4 (CTLA-4), found on chromosmone $2 \mathrm{q} 33$, is considered to be the third susceptibility lo- 


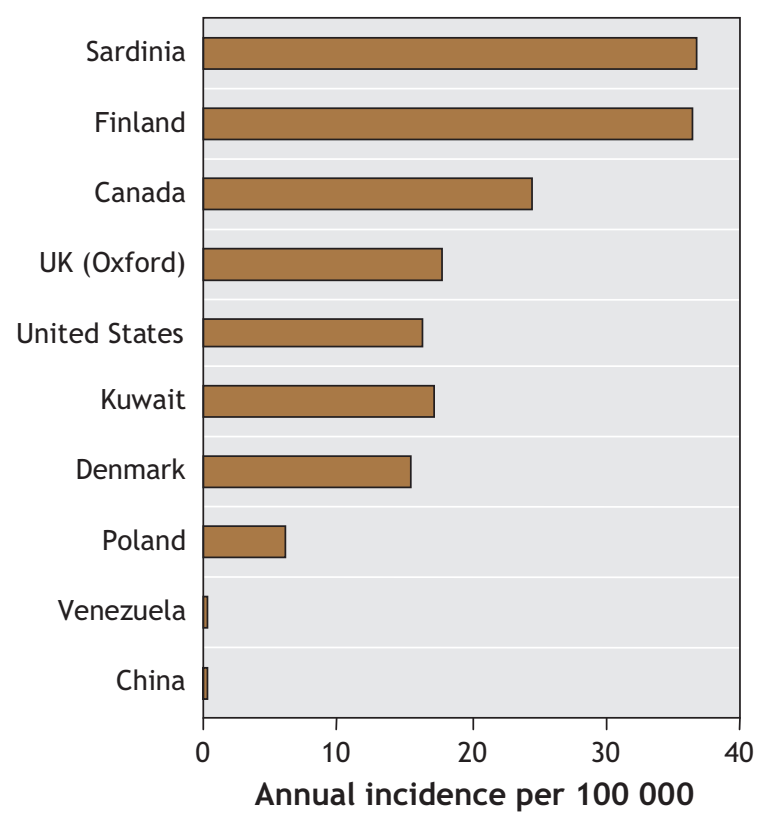

Fig 1: Geographic variation in annual incidence of type 1 diabetes.

cus for type I diabetes and has been associated with increased levels of soluble CTLA-4 ${ }^{19}$ and the frequency of regulatory T cells. ${ }^{20} \mathrm{~A}$ variant of PTPN22, the gene encoding LYP, also a suppressor of T-cell activation, has been deemed the fourth susceptibility factor. ${ }^{21,22}$ The observation that the 4 most important susceptibility genes for type I diabetes can all be represented on a single diagram of antigen presentation to $\mathrm{T}$ cells (Fig. 2) emphasizes the potential importance of current therapeutic strategies targeting this interaction. It is also worth noting that the HLA, CTLA-4 and PTPN22 have all been implicated in autoimmune thyroid disease and other autoimmune diseases, ${ }^{23}$ which supports the premise that similar or overlapping biological pathways contribute to different autoimmune diseases. ${ }^{24}$

Genetic studies have highlighted the importance of large, well-characterized populations in the identification of susceptibility genes for type I diabetes. Recruitment of increasingly large populations of patients with type I diabetes and their families is underway (www.t1dgc.org) to provide statistically powerful cohorts in which to identify other diseaseassociated genes. Some genes will have a relatively minor individual impact on susceptibility to disease but could nevertheless provide more clues to future preventive therapies. The genes for intercellular adhesion molecule (ICAM) and vitamin $\mathrm{D}$ are candidates. Some epidemiologic observations support a protective role for vitamin D in type I diabetes. Maternal intake of vitamin $\mathrm{D}$ in pregnancy and high doses of vitamin $\mathrm{D}$ supplements early in life have been shown to protect against islet autoimmunity in offspring, ${ }^{25,26}$ whereas children with a diagnosis of rickets in the first year of life have been found to have a 3 -fold increased risk of type I diabetes later in life. ${ }^{27}$ Further safety studies of vitamin $\mathrm{D}$ doses in pregnancy are required. ${ }^{28}$ Genetic data on type I diabetes and vitamin D remain controversial. ${ }^{29,30}$ The gene for ICAM-I, associated with an increased risk of type I diabetes, may contribute to the homing and activation of mononuclear cells in the islets during infection and an early autoimmune response, although confirmatory studies are required. ${ }^{31}$

\section{Genetic and environmental interactions}

Studies in most populations confirm an increase in the incidence of type I diabetes, particularly among young children, with the greatest increase occurring in the previously lowincidence countries of eastern Europe. Some studies, ${ }^{32,33}$ however, have shown convincingly that the increases among young children are occurring because of a shift to lower age at onset rather than an overall increase in incidence in all age groups. These changes are too rapid to be caused by alterations in the genetic background and are likely the result of environmental changes. This is confirmed by recent experiments showing that the increase in type I diabetes has been accompanied by a concomitant widening of the HLA risk profile, which suggests increased environmental pressure on susceptible genotypes. ${ }^{34,35}$

Identification of such environmental factors has proved frustratingly difficult. The most popular candidates are viruses, with enteroviruses, ${ }^{36}$ rotavirus ${ }^{37}$ and rubella being suspects. The strongest data to date have supported a role for rubella. Infants infected with congenital rubella syndrome are said to be at increased risk of type I diabetes. ${ }^{38}$ Yet Finland, where vaccination has effectively eradicated rubella, still has one of the highest incidences of type I diabetes. ${ }^{39}$ There is also evidence that some enteroviruses (e.g., Coxsackie B viruses) are less prevalent in countries with high incidences of type I diabetes (e.g., Finland) than in countries with low incidences but geographically similar populations (e.g., Russian Karelia). ${ }^{40}$ This observation may be in keeping with the concept of the hygiene hypothesis, ${ }^{41,42}$ which proposes that environmental exposure to microbes, other pathogens and their products early in life promotes innate immune responses that suppress atopy and perhaps autoimmunity. In Western cultures, the developing immune system of the infant is no longer exposed to widespread infection, which may contribute to the current increases in incidence observed in atopic and autoimmune disease.

Large studies are required to address the role of environmental factors in susceptibility to type I diabetes. An international consortium - the Environmental Determinants of Diabetes in the Young (TEDDY; www.niddk.nih.gov/patient /TEDDY/TEDDY.htm) - has been established to follow several thousand babies with high-risk HLA genotypes from birth until adolescence to identify infectious agents, dietary factors or other environmental factors that trigger islet autoimmunity in genetically susceptible people.

\section{Do we know who is at greatest risk?}

More than 30 years ago, it was recognized that antibodies in sera from patients with type I diabetes could bind to sections of pancreatic islets. These antibodies were termed islet cell an- 
tibodies. The 3 principal autoantigens identified were glutamic acid decarboxylase (GAD 65$),{ }^{43}$ a protein tyrosine phosphatase-like molecule (IA-2) ${ }^{44}$ and insulin. ${ }^{45}$ Studies involving first-degree relatives gave insight into the potential usefulness of islet cell antibodies as predictors of future disease, but the immunoflourescence assay proved difficult to standardize. International workshops to standardize assays for antibodies to GAD, IA-2 and insulin have been more successfull, ${ }^{46,47}$ and it is now clear that about $90 \%$ of people with newly diagnosed type I diabetes have autoantibodies to at least I of these 3 antigens. There is variability in the pattern of humoural immunity, however: insulin autoantibodies are more prevalent in young children, ${ }^{48}$ IA-2 antibodies often decrease after diagnosis, ${ }^{49}$ and antibodies to GAD tend to persist. ${ }^{50}$ It is in the pre-diabetes phase that islet autoantibodies have been most useful. They appear to be already present in most cases of future diabetes by the age of 5 years. ${ }^{51}$ This indicates that the autoimmune process "smoulders" subclinically for many years in the majority of patients and that clinical symptoms do not appear until up to $80 \%$ of $\beta$ cells have been destroyed.

The observations that islet cell autoantibodies predict autoimmune diabetes in first-degree relatives, ${ }^{52}$ that the pres- ence of 2 or more autoantibodies in people in the general population is highly predictive of future disease $\mathrm{e}^{53}$ and that recent reports have shown that people who have IA-2 antibodies are at very high risk ${ }^{54,55}$ have opened the way for intervention strategies to delay or slow the autoimmune process. Identification of appropriate agents to reverse or delay the autoimmune process in people found to have 2 or more islet cell autoantibodies is one of the main targets of diabetes research.

Prevention of the disease process before the appearance of islet cell autoantibodies would be ideal, but the accuracy of prediction based on the presence of genes associated with type I diabetes is limited. In a study involving patients with islet cell autoantibodies in Belguim, HLA class II genotyping identified a subgroup who represented less than 10\% of the Belgian population but who accounted for the majority of future cases of type I diabetes in childhood or early adulthood. ${ }^{56}$ Targeting 10\% of the population for therapeutic intervention, however, when the vast majority will not go on to have type I diabetes would require a highly effective and safe intervention. Population screening strategies for islet cell autoantibodies can be aided by HLA screening strategies,

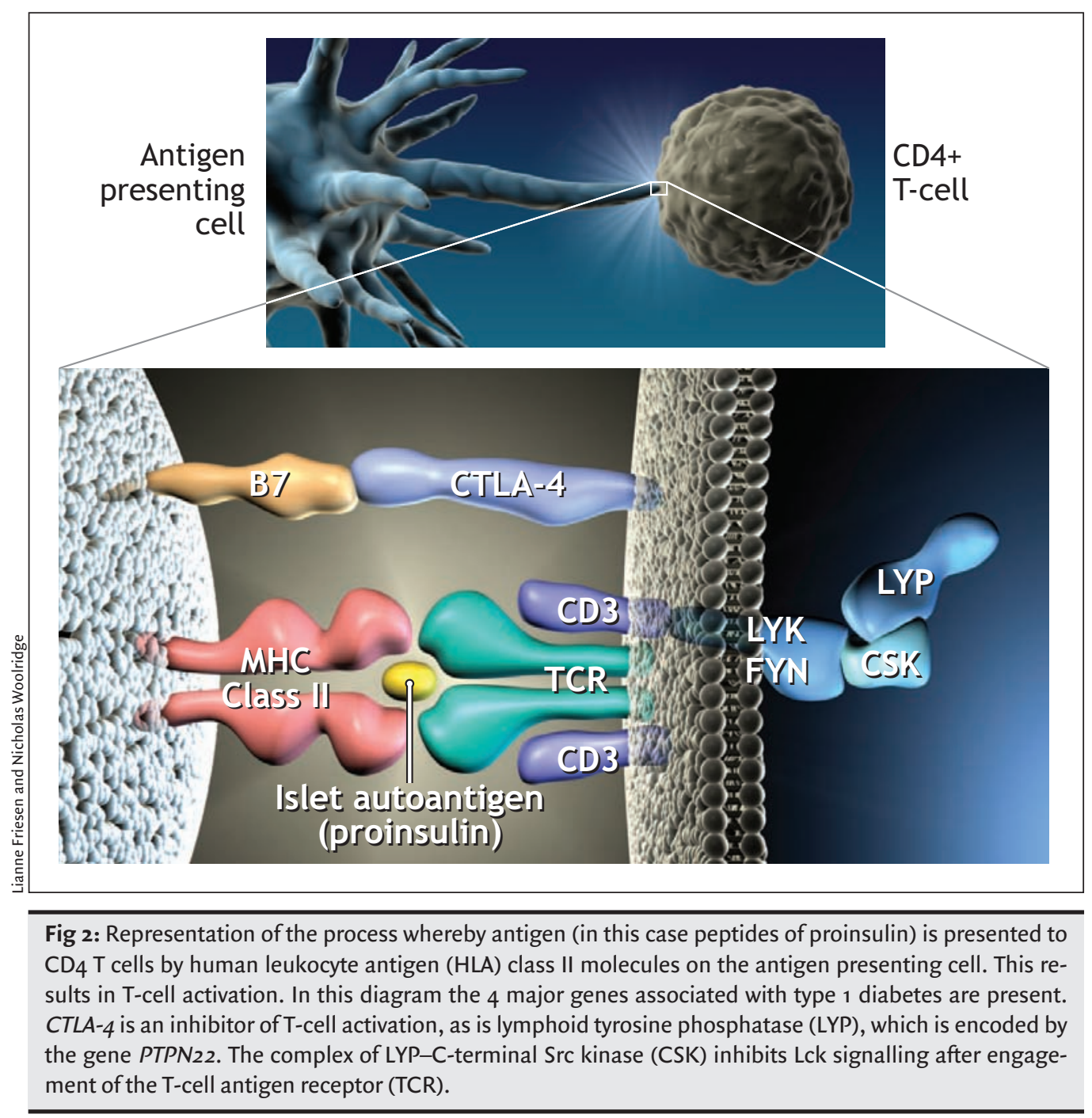

CMAJ $\cdot$ JULY 18, $2006 \cdot 175(2) \quad \mid 167$ 
since $90 \%$ of people in whom type I diabetes will later develop are found to be positive for one or both of the HLA susceptibility haplotypes (DR3-DQ2 and DR4-DQ8) and negative for the protective haplotype (DR2-DQ6). This strategy is being used by the type I Diabetes Prediction and Prevention Study (DIPP) ${ }^{57}$ to test the effectiveness of intranasally applied insulin as an antigen-specific therapy.

\section{Therapeutic interventions}

Two major trials of ways to prevent or delay the onset of type I diabetes are complete.

The European Nicotinamide Diabetes Intervention Trial (ENDIT), a randomized double-blind placebo-controlled trial of high-dose nicotinamide therapy, recruited firstdegree relatives of people who were less than 20 years old when their type I diabetes was diagnosed, were ICA positive, were less than 40 and had a nondiabetic oral glucose tolerance test. Although nicotinamide had proved protective in animal studies, no effect was observed in the ENDIT study during the 5 -year test period. ${ }^{58}$

A trial that ran concurrently with ENDIT, the Diabetes Prevention Trial - type I (DPT-I), studied the efficacy of lowdose insulin injections in high-risk ( $>50 \%$ ) first-degree relatives of patients with type I diabetes. In addition, oral insulin capsules were compared with placebo capsules in relatives with a $25 \%-50 \%$ risk of type I diabetes. Overall, the insulin treatments had no effect, ${ }^{59}$ but in a subset of participants in the oral insulin group (those with high levels of insulin autoantibodies), a delay and perhaps a reduction in the incidence of type I diabetes was observed. ${ }^{60}$ Recent data suggesting that insulin is a primary autoantigen in type I diabetes ${ }^{61,62}$ strengthen the case for a therapeutic focus on insulin.

Both the ENDIT and DPT-I trials, although reporting largely negative findings, have set the standard for future tri- als and emphasized the requirement for international collaboration to facilitate well-designed trials. To this end, TrialNet (www.diabetestrialnet.org) has been established. TrialNet is a network of I8 clinical centres working in cooperation with screening sites throughout the United States, Canada, Finland, the United Kingdom, Italy, Germany, Australia and New Zealand.

Other studies are examining anti-T-cell strategies. Early studies of cyclosporin in the I 980 s provided a proof of principal for the usefulness of immunomodulators in the treatment of type I diabetes; the adverse effects of cyclosporin, however, were incompatible with their widespread use. ${ }^{63,64}$ More sophisticated anti-T-cell strategies have been developed more recently. In one study, hOKT $3 \gamma_{1}($ Ala-Ala), a humanized, modified anti-CD3 monoclonal antibody, was given to 2I patients within 6 weeks of type I diabetes diagnosis; patients in the treatment group had improved C-peptide responses, with effects lasting more than I year after a single course of treatment and without chronic immunosuppression. ${ }^{65}$ In another study, 8o patients with newly diagnosed type I diabetes were randomly assigned to receive either an anti- $\mathrm{CD}_{3}$ monoclonal antibody $\left(\mathrm{ChAglyCD}_{3}\right)$ or placebo; results indicated that residual $\beta$-cell function was maintained for at least I 8 months and that the effect was strongest in those with the greatest residual $\beta$-cell function at study entry. ${ }^{66}$

In the hOKT $3 \gamma_{\mathrm{I}}(\mathrm{Ala}$-Ala) trial, analysis of peripheral blood samples demonstrated an increase in the $\mathrm{CD} 8 / \mathrm{CD}_{4}$ ratio and in particular an increase in CD8+CD25+ regulatory T cells. ${ }^{67}$ Most studies of regulatory $\mathrm{T}$ cells have focused on a subset of naturally occurring $\mathrm{CD}_{4}+$ cells that have the capacity to control self-reactive T cells, ${ }^{68}$ and their depletion results in autoimmunity. ${ }^{69}$ Strategies that target the action of regulatory $\mathrm{T}$ cells in vivo offer one of the most attractive options for therapy in type I diabetes and other autoimmune diseases.

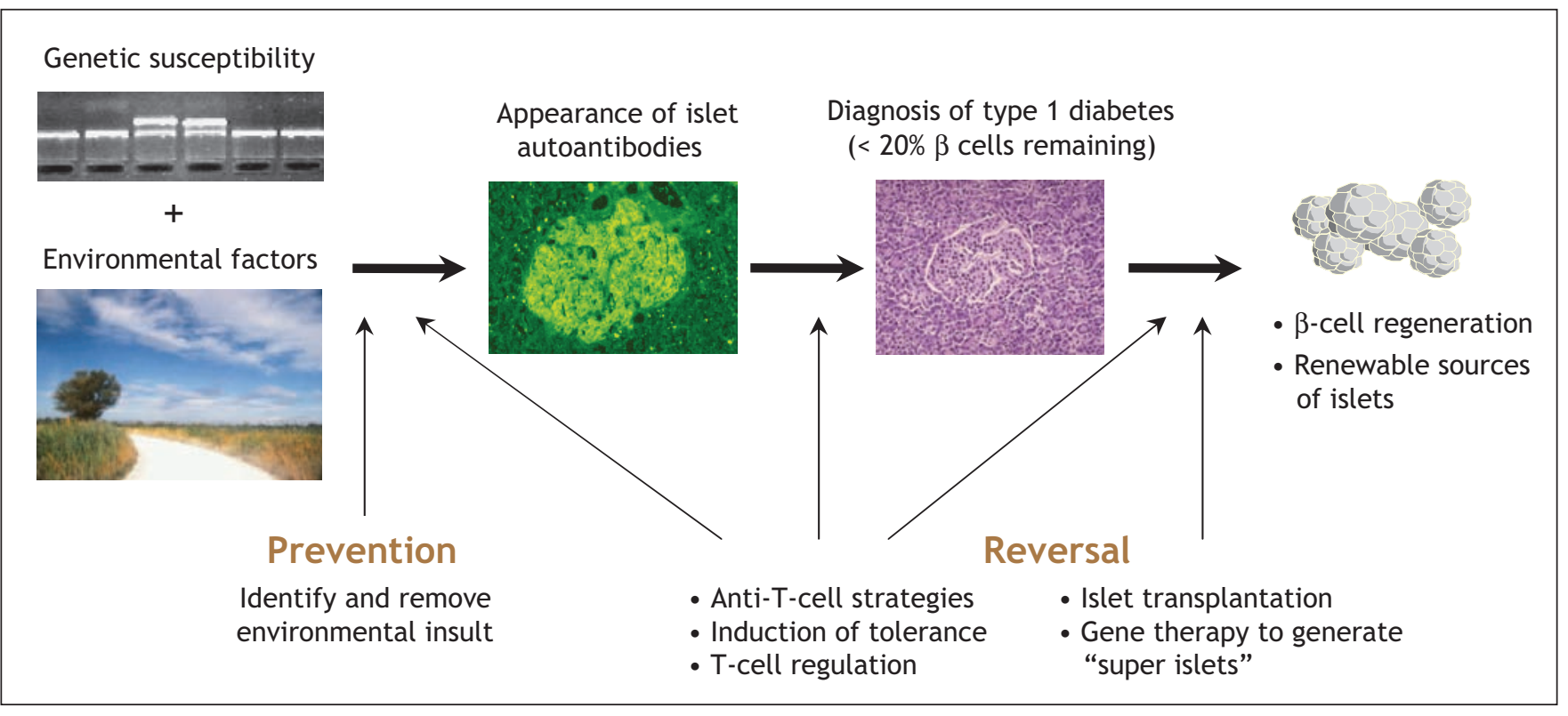

Fig 3: Potential targets for therapeutic intervention of type 1 diabetes. 


\section{Transplantation}

Pancreatic transplantation has offered a successful therapeutic approach for many years. ${ }^{70,71}$ However, as with all whole-organ transplants, lifelong immunosuppression is required and donor organs are in short supply. An alternative strategy, injection of donor islets into the liver, although less invasive, was found to have mixed success until researchers in Edmonton presented the so-called "Edmonton protocol." ${ }^{72}$ With the use of a combination of daclizumab, sirolimus and tacrolimus and islets from more than I donor pancreas per recipient, success rates of $80 \%$ at I year and $20 \%$ at 5 years have been reported. ${ }^{73}$ One of the variables that must be standardized is the crucial islet isolation step. ${ }^{74}$ Both the quality and the number of islets affect success rates. A prospective multicentre trial coordinated by the Immune Tolerance Network has been established to replicate this success. Like pancreatic transplantation, the procedure is currently limited by availability of donor islets. New sources of functional islets will be required for islet transplantation to make a significant impact on type I diabetes.

\section{Regeneration of $\beta$ cells}

The presence of $\beta$ cells in patients with long-standing type I diabetes, despite ongoing autoimmunity, implies that new formation of $\beta$ cells may be occurring. ${ }^{75}$ Although an ambitious aim currently, targeted regeneration of such $\beta$ cells offers another strategy to prevent type I diabetes. Regeneration of $\beta$ cells is therefore an area of major active investigation, with recent studies reporting differentiation of pancreatic and nonpancreatic progenitors as well as replication of existing islet $\beta$ cells. One study has shown that a single, murine, adult pancreatic precursor exists that can differentiate into cells with the characteristics of islet $\beta$ cells. ${ }^{76}$ Another study has shown that pre-existing $\beta$ cells, rather than pluripotent stem cells, are the main source of new $\beta$ cells during adult life and after pancreatectomy in mice. ${ }^{77}$

\section{The future}

We are still some way from developing a pill to prevent type I diabetes, but all the divergent strands of ongoing research, from epidemiology to molecular biology, immunology to clinical trials, appear to be converging to provide clear perspectives on the therapeutic interventions that are most likely to be successful. Two strategies are open to physicians who have patients with type I diabetes: the first is to prevent initiation of autoimmunity; the second is to reverse the effects of ongoing autoimmunity coupled with $\beta$-cell regeneration (Fig. 3). Although highly ambitious, the prevention of type I diabetes could be possible by identifying and eliminating environmental risk factors. The next line of defence would be to re-educate the immune system through exposure to $\beta$-cell antigens with the use of oral or nasal tolerance strategies. The observation that insulin may be the primary autoantigen provides support for therapies using insulin to induce toler- ance. The potential to re-educate the immune system, or to divert it using regulatory $\mathrm{T}$ cells, and the rapidly expanding field of islet $\beta$-cell differentiation give hope that improved strategies to manage this chronic disease are on the horizon.

This article has been peer reviewed.

Kathleen Gillespie is a lecturer with the Department of Clinical Science at North Bristol, University of Bristol, UK.

Competing interests: None declared.

\section{REFERENCES}

I. Foulis AK, McGill M, Farquharson MA. Insulitis in type I (insulin-dependent) diabetes mellitus in man - macrophages, lymphocytes, and interferon-gamma containing cells. J Pathol 1991;165:97-103.

2. EURODIAB ACE Study Group. Variation and trends in incidence of childhood diabetes in Europe. Lancet 2000;355:873-6.

3. Onkamo P, Vaananen S, Karvonen M, et al. Worldwide increase in incidence of type I diabetes - the analysis of the data on published incidence trends. Diabetologia I999;42:1395-403.

4. Cudworth AG, Woodrow JC. HLA system and diabetes mellitus. Diabetes 1975;24: 345-9.

5. Nerup J, Platz P, Andersen OO, et al. HLA antigens and diabetes mellitus. Lancet 1974;2:864-6.

6. Risch N. Assessing the role of HLA-linked and unlinked determinants of disease. Am J Hum Genet 1987;40:I-I4.

7. Todd JA. Genetic analysis of type I diabetes using whole genome approaches. Proc Natl Acad Sci U S A 1995;92:8560-6.

8. Devendra D, Eisenbarth GS. Immunologic endocrine disorders. J Allergy Clin Immunol 2003;III:S624-36.

9. Eisenbarth GS, Gottlieb PA. Autoimmune polyendocrine syndromes. N Engl J Med 2004;350:2068-79.

Io. Caillat-Zucman S, Garchon HJ, Timsit J, et al. Age-dependent HLA genetic heterogeneity of type I insulin-dependent diabetes mellitus. JClin Invest I992;90:2242-50.

II. Gillespie KM, Gale EAM, Bingley PJ. High familial risk and genetic susceptibility in early onset childhood diabetes. Diabetes 2002;51:210-4.

I2. Bell GI, Horita S, Karam JH. A polymorphic locus near the insulin gene is associated with insulin-dependent diabetes mellitus. Diabetes 1984;33:176-83.

13. Bennett ST, Lucassen AM, Gough SCL, et al. Susceptibility to human type I diabetes at IDDM2 is determined by tandem repeat variation at the insulin gene minisatellite locus. Nat Genet 1995;9:284-92.

I4. Vafiadis P, Bennett ST, Todd JA, et al. Insulin expression in human thymus is modulated by INS VNTR alleles at the IDDM2 locus. Nat Genet 1997;15:289-92.

15. Pugliese A, Zeller M, Fernandez A Jr, et al. The insulin gene is transcribed in the human thymus and transcription levels correlated with allelic variation at the INS VNTR-IDDM2 susceptibility locus for type I diabetes. Nat Genet I997;15:293-7.

I6. Mein CA, Esposito L, Dunn MG, et al. A search for type I diabetes susceptibility genes in families from the United Kingdom. Nat Genet 1998;19:297-300.

I7. Concannon P, Gogolin-Ewens KJ, Hinds DA, et al. A second-generation screen of the human genome for susceptibility to insulin-dependent diabetes mellitus. Nat Genet 1998;19:292-6.

I8. Cox NJ, Wapelhorst B, Morrison VA, et al. Seven regions of the genome show evidence of linkage to type I diabetes in a consensus analysis of 767 multiplex families. Am J Hum Genet 2001;69:820-30.

19. Ueda H, Howson JM, Esposito L, et al. Association of the T-cell regulatory gene CTLA4 with susceptibility to autoimmune disease. Nature 2003;423:506-II.

20. Atabani SF, Thio CL, Divanovic S, et al. Association of CTLA4 polymorphism with regulatory T cell frequency. Eur J Immunol 2005;35:2157-62.

2I. Bottini N, Musumeci L, Alonso A, et al. A functional variant of lymphoid tyrosine phosphatase is associated with type I diabetes. Nat Genet 2004;36:337-8.

22. Smyth D, Cooper JD, Collins JE, et al. Replication of an association between the lymphoid tyrosine phosphatase locus (LYP/PTPN22) with type I diabetes, and evidence for its role as a general autoimmunity locus. Diabetes 2004;53:3020-3.

23. Gregersen PK. Gaining insight into PTPN22 and autoimmunity. Nat Genet 2005; 37:1300-2.

24. Becker KG. Comparative genetics of type I diabetes and autoimmune disease: Common loci, common pathways? Diabetes 1999;48:1353-8.

25. Fronczak $\mathrm{CM}$, Baron $\mathrm{AE}$, Chase $\mathrm{HP}$, et al. In utero dietary exposures and risk of islet autoimmunity in children. Diabetes Care 2003;26:3237-42.

26. Hyppönen E, Läärä E, Reunanen A, et al. Intake of vitamin D and risk of type I diabetes: a birth cohort study. Lancet 2001;358:1500-3.

27. Mathieu C, Badenhoop K. Vitamin D and type I diabetes mellitus: state of the art. Trends Endocrinol Metab 2005;16:26I-6.

28. Mahomed K, Gulmezoglu AM. Vitamin D supplementation in pregnancy [review]. Cochrane Database Syst Rev 2000;(2):CDooo228.

29. Nejentsev S, Cooper JD, Godfrey L, et al. Analysis of the vitamin D receptor gene sequence variants in type I diabetes. Diabetes 2004;53:2709-I2. 
30. Pani MA, Knapp M, Donner H, et al. Vitamin D receptor allele combinations influence genetic susceptibility to type I diabetes in Germans. Diabetes 2000;49:504-7.

3I. Nejentsev S, Guja C, McCormack R, et al. Association of intercellular adhesion molecule-I gene with type I diabetes. Lancet 2003;362:1723-4.

32. Pundziute-Lycka A, Dahlquist G, Nystrom L, et al. Incidence of type I diabetes has not increased but shifted to a younger age at diagnosis in the 34 years group in Sweden 1983-1998. Diabetologia 2002;45:783-91.

33. Weets I, De Leeuw IH, Du Caju MV, et al. The incidence of type I diabetes in the age group o-39 years has not increased in Antwerp (Belgium) between 1989 and 2000: evidence for earlier disease manifestation. Diabetes Care 2002;25:840-6.

34. Hermann R, Knip M, Veijola R, et al. Temporal changes in the frequencies of HLA genotypes in patients with type I diabetes - Indication of an increased environmental pressure? Diabetologia 2003;46:420-5.

35. Gillespie KM, Bain SC, Barnett AH, et al. The rising incidence of childhood type I diabetes and reduced contribution of high-risk HLA haplotypes. Lancet 2004;364: I699-700.

36. Hyoty H. Enterovirus infections and type I diabetes. Ann Med 2002;34:138-47.

37. Honeyman MC, Coulson BS, Stone NL, et al. Association between rotavirus infection and pancreatic islet autoimmunity in children at risk of developing type I diabetes. Diabetes 2000;49:1319-24.

38. Ginsberg-Fellner F, Witt ME, Fedun B, et al. Diabetes mellitus and autoimmunity in patients with the congenital rubella syndrome. Rev Infect Dis I985;7(Suppl I):Si7o-6.

39. Peltola H, Davidkin I, Paunio M, et al. Mumps and rubella eliminated from Finland. JAMA 2000;284:2643-7.

40. Viskari H, Ludvigsson J, Uibo R, et al. Relationship between the incidence of type I diabetes and maternal enterovirus antibodies: time trends and geographical variation. Diabetologia 2005;48:1280-7.

4I. Gale EA. A missing link in the hygiene hypothesis? Diabetologia 2002;45:588-94.

42. Bach JF. Infections and autoimmune diseases. JAutoimmun 2005;25:74-80.

43. Baekkeskov S, Warnock G, Christie M, et al. Revelation of specificity of $64 \mathrm{~K}$ autoantibodies in IDDM serums by high-resolution 2-D gel electrophoresis. Unambiguous identification of $64 \mathrm{~K}$ target antigen. Diabetes I989;38:II33-4I.

44. Lan MS, Wasserfall C, Maclaren NK et al. IA-2, a transmembrane protein of the protein tyrosine phosphatase family, is a major autoantigen in insulin-dependent diabetes mellitus. Proc Natl Acad Sci U S A. 1996 25; 93:6367-70.

45. Palmer JP. Insulin autoantibodies: their role in the pathogenesis of IDDM. Diabetes Metab Rev I987;3:1005-I5.

46. Verge CF, Stenger D, Bonifacio E, et al. Combined use of autoantibodies (IA-2 autoantibody, GAD autoantibody, insulin autoantibody, cytoplasmic islet cell antibodies) in type I diabetes: Combinatorial Islet Autoantibody Workshop. Diabetes 1998;47:1857-66.

47. Bingley PJ, Bonifacio E, Mueller PW. Diabetes Antibody Standardization Program: first assay proficiency evaluation. Diabetes 2003;52:1128-36.

48. Vandewalle CL, Decraene T, Schuit FC, et al. Insulin autoantibodies and high titre islet cell antibodies are preferentially associated with the HLA DQAI*030I$\mathrm{DQBI}{ }^{\star} 0302$ haplotype at clinical type I (insulin-dependent) diabetes mellitus before age ro years, but not at onset between age ro and 40 years. The Belgian Diabetes Registry. Diabetologia 1993;36:II55-62.

49. Gorus FK, Goubert P, Semakula C, et al. IA-2-autoantibodies complement GAD65autoantibodies in new-onset IDDM patients and help predict impending diabetes in their siblings. The Belgian Diabetes Registry. Diabetologia 1997;40:95-9.

50. Decochez K, Tits J, Coolens JL. High frequency of persisting or increasing isletspecific autoantibody levels after diagnosis of type I diabetes presenting before 40 years of age. The Belgian Diabetes Registry. Diabetes Care 2000;23:838-44.

5I. Ziegler A.G., Hummel M., Schenker M., et al. Autoantibody appearance and risk for development of childhood diabetes in offspring of parents with type I diabetes: the 2-year analysis of the German BABYDIAB Study. Diabetes 1999;48:460-8.

52. Bingley PJ, Williams AJK, Gale EAM. Optimized autoantibody-based risk assessment in family members. Diabetes Care I999;22:1796-80I.

53. Bingley PJ, Bonifacio E, Williams AJK, et al. Prediction of IDDM in the general population. Strategies based on combinations of autoantibody markers. Diabetes 1997;46:170I-10.

54. Decochez K, Truyen I, van der Auwera B, et al. Combined positivity for HLA DQ2/DQ8 and IA-2 antibodies defines populations at high risk of developing type I diabetes. Diabetologia 2005;48:687-94.

55. Achenbach P, Warncke K, Reiter J, et al. Stratification of type I diabetes risk on the basis of islet autoantibody characteristics. Diabetes 2004;53:384-9.
56. Van der Auwera BJ, Schuit FC, Weets I, et al. Relative and absolute HLA-DQAIDQBI linked risk for developing type I diabetes before 40 years of age in the Belgian population: implications for future prevention studies. Hum Immunol 2002; 63:40-50.

57. Nejentsev S, Sjoroos M, Soukka T, et al. Population-based genetic screening for the estimation of type I diabetes mellitus risk in Finland: selective genotyping of markers in the HLA-DQBI, HLA-DQAI and HLA-DRBI loci. Diabet Med I999;16:985-92.

58. Gale EA, Bingley PJ, Emmett CL, et al. European Nicotinamide Diabetes Intervention Trial (ENDIT): a randomised controlled trial of intervention before the onset of type I diabetes. Lancet 2004;363:925-3I.

59. Diabetes Prevention Trial-Type I Diabetes Study Group: Effects of insulin in relatives of patients with type I diabetes mellitus. NEngl J Med 2002;346:1685-9I.

6o. Skyler JS, Krischer JP, Wolfsdorf J, et al. Effects of oral insulin in relatives of patients with type I diabetes: the Diabetes Prevention Trial-Type I. Diabetes Care 2005;28:1068-76.

6I. Kent SC, Chen Y, Bregoli L, et al. Expanded T cells from pancreatic lymph nodes of type I diabetic subjects recognize an insulin epitope. Nature 2005;435:224-8.

62. Nakayama $\mathrm{M}$, Abiru $\mathrm{N}$, Moriyama $\mathrm{H}$, et al. Prime role for an insulin epitope in the development of type I diabetes in NOD mice. Nature 2005;435:220-3.

63. Feutren G, Papoz L, Assan R, et al. Cyclosporin increases the rate and length of remissions in insulin-dependent diabetes of recent onset. Results of a multicentre double-blind trial. Lancet 1986;2:119-24.

64. Canadian-European Randomized Control Trial Group. Cyclosporin-induced remission of IDDM after early intervention. Association of I yr of cyclosporin treatment with enhanced insulin secretion. Diabetes 1988;37:1574-82.

65. Herold KC, Gitelman SE, Masharani U, et al. A single course of anti- $\mathrm{CD}_{3}$ monoclonal antibody hOKT3gammar(Ala-Ala) results in improvement in C-peptide responses and clinical parameters for at least 2 years after onset of type I diabetes. Diabetes 2005;54:1763-9.

66. Keymeulen B, Vandemeulebroucke E, Ziegler AG, et al. Insulin needs after $\mathrm{CD}_{3}$ antibody therapy in new-onset type I diabetes. N Engl J Med 2005;352:2598-608.

67. Bisikirska B, Colgan J, Luban J, et al. TCR stimulation with modified anti-CD 3 $\mathrm{mAb}$ expands CD8+ T cell population and induces CD8+CD 25+ Tregs. J Clin Invest 2005;II5:2904-I3.

68. Sakaguchi S. Regulatory T cells: key controllers of immunologic self-tolerance. Cell 2000; IOI:455-8.

69. DiPaolo RJ, Glass DD, Bijwaard KE, et al. $\mathrm{CD}_{4}+\mathrm{CD}_{25}+\mathrm{T}$ cells prevent the development of organ-specific autoimmune disease by inhibiting the differentiation of autoreactive effector T cells. JImmunol 2005;175:7135-42.

70. Burke GW, Ciancio G, Sollinger HW. Advances in pancreas transplantation. Transplantation 2004 I5;77:S62-7.

7I. Gruessner AC, Sutherland DE. Pancreas transplant outcomes for United States (US) and non-US cases as reported to the United Network for Organ Sharing (UNOS) and the International Pancreas Transplant Registry (IPTR) as of June 2004. Clin Transplant 2005;19:433-55.

72. Shapiro AM, Lakey JR, Ryan EA, et al. Islet transplantation in seven patients with type I diabetes mellitus using a glucocorticoid-free immunosuppressive regimen. NEngl J Med 2000;343:230-8.

73. Ryan EA, Paty BW, Senior PA, et al. Five-year follow-up after clinical islet transplantation. Diabetes 2005;54:2060-9.

74. Ricordi C. Islet transplantation: a brave new world. Diabetes 2003;52:1595-603.

75. Meier JJ, Bhushan A, Butler AE. Sustained beta cell apoptosis in patients with long standing type I diabetes: Indirect evidence for islet regeneration? Diabetologia 2005;48:222I-8.

76. Seaberg RM, Smukler SR, Kieffer TJ. Clonal identification of multipotent precursors from adult mouse pancreas that generate neural and pancreatic lineages. Nat Biotechnol 2004;22:1115-24

77. Dor Y, Brown J, Martinez OI. Adult pancreatic beat-cells are formed by self-duplication rather than stem-cell differentiation. Nature 2004;429:4I-6.

Correspondence to: Dr. Kathleen M. Gillespie, Medical School Unit, Southmead Hospital, Bristol BSio 5NB, UK; fax +44 II7 959 5336; k.m.gillespie@bristol.ac.uk 